„Kwartalnik Filmowy” nr 111 (2020)

ISSN: 0452-9502 (Print) ISSN: 2719-2725 (Online)

https://doi.org/10.36744/kf.402

(c) Creative Commons BY-NC-ND 4.0

\title{
Łucja Demby
}

Uniwersytet Jagielloński

https://orcid.org/oooo-0001-8786-9849

\section{Zdalne kino. Samotność widza wobec zmysłowego charakteru recepcji filmu}

\author{
Słowa kluczowe: \\ teoria filmu; \\ teoria widza \\ filmowego; \\ doświadczenie \\ filmowe; \\ kino zdalne; \\ teoria zmysłowa
}

\begin{abstract}
Abstrakt
Autorka zwraca uwagę na nowe zjawisko, jakie pojawiło się w czasie epidemii koronawirusa: tzw. zdalne kino. Zastanawia się, pod jakim względem ta nowa sytuacja różni się od zwyczajnego oglądania filmu online. Rozważania te są prowadzone w kontekście wybranych wątków teorii filmu dotyczących dystansu widza wobec filmu i przede wszystkim wobec innych widzów na sali kinowej. Autorka odnosi się do dominującej w ostatnich latach sensuous theory, ale także do wcześniejszych koncepcji teoretycznych (m.in. do teorii psychoanalitycznej), podkreślając, że dzisiejsza refleksja nad filmem jest w nich w dużym stopniu zakorzeniona. W doświadczeniu kina najbardziej interesuje ją paradoksalna samotność widza. Autorka odnosi się także do przykładów filmowych, wśród których na plan pierwszy wysuwa się Ucieczka z kina Wolność (1990) Wojciecha Marczewskiego.
\end{abstract}


Kino może być cytrusowym zapachem obieranej pomarańczy, dotykiem cieptej skóry pod jedwabna pończochą lub po prostu sala, zatopiona w ciemnościach, skapana w uczuciu oczekiwania.

Wong Kar Wai ${ }^{1}$

Kiedy w czasie pandemii koronawirusa w marcu 2020 r. zostały zamknięte wszelkie instytucje kultury, dość powszechny stał się obyczaj udostępniania przez nie zasobów za pośrednictwem serwisów internetowych. Teatry otworzyły archiwa z nagraniami dawnych arcydzieł sceny, muzea udostępniły możliwość wirtualnego zwiedzania swoich wnętrz. Któregoś dnia otrzymałam wiadomość, że usługę taką - możliwość nabycia biletu na domowe seanse filmów z bieżącego repertuaru - oferuje także krakowskie Kino Pod Baranami.

W pierwszej chwili wydawało się to naturalne: kino dołączyło po prostu do oferty kulturalnej „czasów zarazy”. Zaraz potem jednak przyszła refleksja: czyż kino (z racji rozdzielenia przestrzeni widza i świata przedstawionego w filmie) z natury swojej nie jest „zdalne”? Czym zatem różni się zdalna oferta kina i teatru? I czym różni się repertuarowa propozycja e-kina od zwykłego oglądania filmu online? Krakowskie kino wyraźnie bowiem o takiej różnicy pisało: Zapraszamy do wirtualnych sal Kina Pod Baranami! (...). To nie jest zwykła platforma VOD, to raczej kino internetowe. W E-Kinie Pod Baranami pokażemy filmy, które jeszcze nie tak dawno można było zobaczyć na ekranie filmowym².

Czy istnieje w ogóle zdalne kino? Kluczowe wydaje się tu przede wszystkim rozróżnienie terminów „,kino” i „film”, które jak wielokrotnie podkreślali teoretycy, nie są wcale synonimami, choć tak właśnie traktuje się je często w mowie potocznej. Kino, choć na przestrzeni swojej ponadstuletniej historii było bardzo różnie definiowane (jako budynek, instytucja, przemysł, sztuka, fakt społeczny czy po prostu miejsce), zawsze zawiera w sobie implicite pierwiastek ponadindywidualny. Jest też przedmiotem nieustannej fascynacji ze strony teoretyków i twórców; nie bez powodu najbardziej przesycone nią filmy to te, które pokazują widzów na sali³ . Za symptomatyczny pod tym względem można uznać fakt, że kiedy, z okazji 60. rocznicy festiwalu w Cannes poproszono najwybitniejszych reżyserów współczesnego kina o zrealizowanie trzyminutowego filmu na jego temat, powstały trzydzieści trzy etiudy poświęcone prawie wyłącznie widzom i sali kinowej. Precyzyjniej rzecz ujmując, nie tyle widzom, ile ich emocjom; doskonale wyraża to tytuł tego zbiorowego filmu, w Polsce rozpowszechnianego pod dość banalnym tytułem Kocham kino (2007): Chacun son cinéma ou Ce petit coup au coeur quand la lumière s'éteint et que le film commence (Każdemu jego kino albo To bicie serca, kiedy gaśnie światło i zaczyna się film).

Kino - to widzowie i uczucia, które im towarzysza, ale także specyficzny klimat sali. O kinowości decyduje dwuznaczny charakter filmowego seansu, w którym tendencja do zanurzenia się całkowicie w świecie obrazowej fikcji rozpraszana jest przez taktylny charakter wnętrza, wypetnionego innymi ciałami i materialnymi przedmiotami ${ }^{4}$ - przypomina Justyna Budzik w jednej z najciekawszych współczesnych książek poświęconych doświadczeniu kina.

Kiedy siedzimy przed ekranem zdalnego kina, dystans, jaki dzieli nas od oglądanego filmu, w sensie obiektywnym niewiele się różni od tego, który towarzyszy oglądowi filmu na przykład z płyty DVD czy platformy VOD. W sensie 
psychologicznym jednak różnicę taką możemy odczuwać, gdyż za zdalnym kinem stoi realna instytucja, pod nazwą danego kina, które budzi konkretne skojarzenia zmysłowe, włącznie z zapachem. Mając (subiektywne) poczucie bycia w (określonym) kinie, widz tym bardziej dojmująco może odczuwać swoje w nim osamotnienie i dystans: „jestem w kinie, ale bardzo daleko od tego kina”. W ten sposób potwierdza on fakt, że w normalnych warunkach pobyt w tym miejscu miałby dla niego znaczenie. Tym, co odróżnia recepcję filmu online od zdalnej oferty kinowej, jest więc świadomość miejsca, odległego przestrzennie, na dystans, ale obecnego w naszym umyśle - pamięć kina.

Przytoczona tu przykładowo (jako charakterystyczna dla naszych czasów) sytuacja oglądania filmu online czy też odtwarzanego w formacie DVD nie wyczerpuje oczywiście listy wszelkich możliwych wariantów recepcji filmu, prowokujących do refleksji nad jej mniej lub bardziej zdalnym charakterem. Historia odchodzenia kina od kina (telewizja, kasety VHS, kino domowe, płyty DVD, wszelkie możliwości, jakie oferuje pod tym względem Internet, platformy streamingowe itp.) z całą pewnością mogłaby być frapującym przedmiotem osobnych badań. Określenie „zdalne kino” można jednak potraktować nie tylko w sposób dosłowny, ale także jako metaforę złożonego i niejednoznacznego charakteru uczestnictwa widza w seansie filmowym, w szczególny sposób angażującego jego zmysły. Sytuacja izolacji społecznej z powodu pandemii w sposób szczególny prowokuje do tego rodzaju refleksji. Przede wszystkim w taki też sposób będę to określenie rozumieć w niniejszym artykule.

$$
* * *
$$

Pamięć kina przywotywać można na różne sposoby, bo mieni się ona rozmaitymi barwami wspomnień, odnoszona bywa do odmiennych przeżyć, ale, co naturalne, pobrzmiewa zawsze własnymi, niepowtarzalnymi emocjami. (...) Sa (...) i tacy, którym pamięć ekranowych światów nakłada się nieuchronnie na konglomerat miejsc i osób, dzięki którym te światy zaistniały: kin, miejscowości, ulic ${ }^{5}$ - pisze Andrzej Gwóźdź w książce poświęconej wspomnieniom miejsc ewokujących przeżycia filmowe. Pamięć, będąc jednym z fundamentów samego filmu, który już Hugo Münsterberg uznał przede wszystkim za "sztukę umysłu”, jest także nierozdzielnie związana z doświadczeniem kina. Kinowa pamięć może osiągać wymiar egzystencjalny, jak w „nowym doświadczeniu widzialności” Jean-Louisa Schefera ${ }^{6}$, kiedy to dzięki obrazom pojawiającym się na ekranie widz przypomina sobie i dopiero $\mathrm{w}$ tym momencie zaczyna rozumieć ważne fakty z własnego życia. Z fragmentów wspomnień i oglądanego filmu w jego umyśle rodzi się swego rodzaju wirtualne dzieło pamięci. W takim egzystencjalnym ujęciu można by uznać kino za odpowiednik, na polu innego medium, ,teatru śmierci” Tadeusza Kantora - w obu wypadkach konstytutywną moc ma akt pamięci wywołujący z przeszłości zastygłe obrazy nacechowanych emocjonalnie wspomnień. W gruncie rzeczy każdy film, przefiltrowany przez umysł widza, mógłby nosić tytuł Amarcord („Przypominam sobie”). Ale z „siódmą sztuką"7 jest też związana pamięć obecności innych ludzi - to ją właśnie ewokuje zdalne kino. Znaczna część wspomnianej książki Justyny Budzik jest rozwinięciem tez zawartych w znanym artykule Rolanda Barthes'a Wychodzac z kina , w którym milcząca lecz zarazem zmysłowa obecność innych wi- 
dzów jest istotnym elementem seansu filmowego kreującym specyficzną atmosferę kina.

Wśród teoretyków zajmujących się tą problematyką w okresie bliższym nam czasowo warto wymienić Juliana Hanicha, holenderskiego fenomenologa filmu, który w swych pracach podkreśla kolektywny charakter seansu kinowego: ogladanie filmu z innymi często oznacza wspólna aktywność oparta na wspólnej intencji zajęcia się pojedynczym obiektem - filmem ${ }^{9}$.

Obecność innych widzów na sali kinowej jest także atrakcyjnym tematem filmowym. To jeden z tych aspektów, w których pojęcia "kino" i "film”, stają się trudne do rozdzielenia, warto zatem poświęcić temu zagadnieniu nieco uwagi. W doświadczeniu kina film pełni rolę dwojaką. Z jednej strony niektóre filmy odwołują się do kina w warstwie fabularnej, inspirując do refleksji nad jego mechanizmami. Zdaniem Jean-Louisa Comolli fakt skupienia kina ${ }^{10}$ na samym sobie (tendencja raczej obca wczesnej kinematografii) jest charakterystyczny zwłaszcza dla naszych czasów, w których sfilmowane zostało już wszystko - pozostaje zatem tylko „metakino”"11. Dodajmy, że „nasze czasy” należy tu potraktować dość szeroko, gdyż filmy, które będą mnie interesować, pochodzą w większości z lat 80 . XX w.; nie jest jednak zapewne przypadkiem, że powstały one właśnie w okresie postmodernistycznego znużenia filmowaniem rzeczywistości.

$\mathrm{Z}$ drugiej zaś strony projekcja filmu jest fundamentalnym i integralnym elementem tego doświadczenia, dlatego w niniejszym tekście istotne będą dla mnie także rozważania nad statusem filmu i relacją pomiędzy nim a widzem. W pierwszym wypadku mamy do czynienia z kinem w filmie, w drugim - z filmem w kinie.

Istnieje wiele filmów, które opowiadają o kinie. W przypadku niektórych bohaterami są widzowie. Ale tylko nieliczne dotyczą tego aspektu kina, który w ostatnich latach w rozważaniach teoretyków zaczął się wysuwać na pierwszy plan - bliskiego, zmysłowego kontaktu widza z filmem. Słowo „,zmysłowy” odnosi się tu, oczywiście, także do wzroku, lecz odbiera mu patent na wyłączność - film odbieramy całym ciałem, istnieją swego rodzaju „oczy skóry”. Taki właśnie tytuł nadał swej książce ${ }^{12}$ fiński architekt Juhani Pallasmaa, lecz zasadne byłoby posługiwanie się nim także w odniesieniu do kina. Emblematycznym wyrazem takiej sytuacji jest pojawiający się w niektórych filmach motyw „oglądania” filmu przez osobę niewidoma, która mimo braku możliwości posługiwania się wzrokiem czerpie niewątpliwe pożytki estetyczne i emocjonalne $\mathrm{z}$ uczestnictwa w seansie. Wątek ten pojawia się między innymi w etiudach ze wspomnianego Kocham kino, przy czym wśród nich na szczególne wyróżnienie zasługuje Anna (reż. Alejandro González Iñárritu), krótka opowieść o czystym wzruszeniu emocjonalnym niewidomej kobiety, która uczestniczy w pokazie Pogardy (Le mépris, reż. Jean-Luc Godard, 1963) wraz z partnerem objaśniającym jej to, co na ekranie. Pytanie, które zadaje mężczyźnie po wyjściu z kina, najpełniej wyraża to, że zmysł wzroku nie był jej w niczym potrzebny do emocjonalnego spełnienia: Czy to był film czarno-biały?

Niewidomy widz, któremu żona opowiada, co dzieje się na ekranie, występuje też w jednym z najpiękniejszych filmów poświęconych miłości do sztuki filmowej - w Kinie Paradiso (Cinema Paradiso, reż. Giuseppe Tornatore, 1988). Operatorowi, który w wyniku pożaru stracił wzrok, nie przeszkadza to wcale w delektowaniu się, wraz z lokalną społecznością, seansem na sali kinowej. Film Tornatore to jeden z trzech najdoskonalszych, w moim mniemaniu, obrazów nie- 
zwykle bliskiej, zmysłowej relacji widza z filmem, która może prowadzić nawet do swoistego zespolenia, przekroczenia dystansu stanowiącego zazwyczaj o specyfice kina. Z całą pewnością należy do niego dołączyć Purpurowa różę z Kairu (Purple Rose of Cairo, reż. Woody Allen, 1985) oraz, na gruncie polskim, Ucieczkę z kina Wolność (reż. Wojciech Marczewski, 1990). Przykłady te można by w pierwszej chwili uznać za banalne, powszechnie znane i często przywoływane, jednakże w znakomity sposób przedstawiają one różne warianty bliskości widza i filmu. Udowadniają też, że temat ten, wbrew pozorom, nie pojawia się wcale w kinie tak często. Do grupy tej można jeszcze dodać Bohatera ostatniej akcji (Last Action Hero, reż. John McTiernan, 1993) (choć różni się on od nich komercyjnym charakterem i tym, że bliski kontakt widza z filmem jest tu w dużej mierze kwestią chwytu technicznego i pretekstem do zabawy konwencjami filmowymi), a także filmy opisywane przez autorkę Dotyku światta w podrozdziałach Postscriptum z widowni, przede wszystkim Marzyciele (The Dreamers, reż. Bernardo Bertolucci, 2003) i Tak daleko, tak blisko (In weiter Ferne, so nah!, reż. Wim Wenders, 1993). Można by także wymieniać tytuły dzieł, w których pojawia się motyw sali kinowej lub po prostu oglądania filmu: Podróże Sullivana (Sullivan's Travels, reż. Preston Sturges, 1941), Amarcord (reż. Federico Fellini, 1973), Historia kina w Popielawach (reż. Jan Jakub Kolski, 1998), Jasminum (reż. Jan Jakub Kolski, 2006) i wiele innych. Odniesienia te mają jednak często charakter fragmentaryczny, a czasem wręcz jedynie anegdotyczny, podczas gdy wymienione wcześniej filmy, mimo swej atrakcyjnej formy kinematograficznej i dużej dawki humoru, są w gruncie rzeczy prawdziwymi traktatami na temat niezwykłego statusu widza w kinie. Kino Paradiso to sentymentalny obraz wspólnotowego modelu recepcji filmu, sytuującego się na przeciwstawnym biegunie niż dominujący w naszej kulturze model widza zanurzonego w ciemnej sali kinowej i samotnie przeżywającego spotkanie z obrazami na ekranie. Bohaterowie tego filmu stanowią wspólnotę nie tylko z innymi widzami, ale także z postaciami oglądanymi na ekranie. W jednej ze znakomitych, komediowo rozegranych scen Kina Paradiso jeden z mężczyzn podczas projekcji przeżywa losy ekranowych bohaterów, wypowiadając na głos ich kwestie parę sekund przed nimi. Scena ta przywodzi na myśl wspomnienia Roberta Flaherty'ego dotyczące sposobu, w jaki Eskimosi identyfikowali się z bohaterem Nanuka z Potnocy (Nanook of the North, reż. Robert Flaherty, 1922) ${ }^{13}$, ale także uwagi Christiana Metza na temat projekcji kinowych w małych miejscowościach w połowie lat 70. XX w. ${ }^{14}$. Purpurowa róża z Kairu natomiast przedstawia kilka odmiennych postaw wobec filmu. Posługując się jedną postacią, Allen łączy różne aspekty kinowej identyfikacji opisywane przez teoretyków. Cecilia jest jednocześnie modelowym widzem $\mathrm{z}$ teorii psychoanalitycznych, zanurzającym się w ciemnościach sali kinowej, aby uciec od rzeczywistości zewnętrznej, jak i widzem naiwnym, nieodróżniającym postaci od aktora, wreszcie także widzem Morinowskim, wobec którego filmowe „widmo" materializuje się i przybiera cielesne kształty. Pewnie dlatego jej identyfikacja emocjonalna z filmem jest tak silna.

Najciekawszym spośród wymienionych przykładów wydaje się jednak Ucieczka z kina Wolność, analizowana zazwyczaj w nieco innym kontekście, w odniesieniu do przemian politycznych w Polsce w końcowym okresie PRL oraz Requiem d-moll Mozarta. Film Marczewskiego, mimo pozornego zanegowania istoty medium, jest w gruncie rzeczy (niejako mimochodem, obok kwestii, które były dla 
reżysera najważniejsze) przenikliwą i subtelną refleksją na temat widza. Ucieczka z kina Wolność mówi o oscylacji między zmysłowym kontaktem z filmem a dystansem, jaki on wymusza, a więc o tym, co w istocie stanowi o specyfice tej sztuki, zarazem bliskiej i dalekiej odbiorcy. Marczewski odsłania różne aspekty kinowego (a więc szerszego niż li tylko filmowy) autotematyzmu. Najpierw ukazuje bunt przeciwko tradycyjnemu modelowi kina, potem zmiany w łonie samego filmu: odejście od miałkiego scenariusza, interpelacje do widza, zatarcie granic między filmem a teatrem. Jednak z dzisiejszej perspektywy uwagę zwraca przede wszystkim sensualny wymiar zaprezentowanej tu sytuacji kinowej. W Ucieczce z kina Wolność Cenzor dotyka ekranu i przenika do świata „po drugiej stronie lustra”, do filmu (trudno byłoby twierdzić, że do filmowej diegezy, gdyż ta uległa już dekonstrukcji). Słowa: Zawsze chciałem tu wejść, które wypowiada, znalazłszy się w innej przestrzeni, można interpretować nie tylko w kontekście wolnościowym, jak się to zazwyczaj czyni (,tu”, czyli po przeciwnej stronie niż władze PRL). Są one także wyrazem tęsknoty widza za zmysłowym kontaktem z tym, co w kinie musi pozostać na dystans, z obrazem filmowym i tym, co on przedstawia. Moment dotknięcia ekranu wydaje się tu kluczowy, można go uznać za najbardziej adekwatną metaforę kinowego status quo widza. Usytuowanie widza wobec rzeczywistości ekranowej przypomina trochę sytuację, w jakiej znajduje się w finale bohater filmu Interstellar (reż. Christopher Nolan, 2014): tkwiąc w innym wymiarze, widzi swoją córkę, ale nie ma możliwości nawiązania z nią bezpośredniego kontaktu; w świecie, który obserwuje, on sam może istnieć tylko jako czysta świadomość, której narzędziem jest zmysł wzroku. Inne zmysły, przede wszystkim dotyk, przypominają o swym istnieniu, kusza, aby nawiązać bliższy kontakt z rzeczywistością ekranową. Zanim Cenzor zdecyduje się na taką próbę, w Ucieczce z kina Wolność pojawiają się już drobne epizody, które sugeruja, że kontakt taki jest możliwy. Z rzeczywistości do filmu przenika płaszcz Cenzora, postaciom z ekranu przeszkadza zapach dymu papierosowego w kinie. Ekran okazuje się zatem być czymś w rodzaju przepuszczalnej błony, przy czym - co charakterystyczne - transfer jest tu raczej jednostronny, w przeciwnym kierunku niż u Allena: to nie postać schodzi z ekranu, ale widz przenika przez ekran. Wprawdzie w zakończeniu Cenzor powróci do rzeczywistości, ale uczyni to nie z własnej woli. Nie chodzi tu już bowiem o to, aby - jak w Purpurowej róży z Kairu - świat filmu przeniknął do naszego życia, wywołując jak największe zaangażowanie emocjonalne i prowokując fetyszyzowanie go (szukanie postaci w realnym aktorze), ale aby jak najbardziej samemu się do niego zbliżyć, chłonąc go wszelkimi zmysłami. Film jest nieosiągalnym przedmiotem tęsknoty, pobudzającym różne zmysły, ale niedającym im całkowitego zaspokojenia. Fakt, że Cenzor zostaje przepędzony z tego świata, można uznać za wyrazisty symbol „wypędzenia” widza z kina po seansie i jego powrotu do codzienności. Pozostaje mu tylko, jak w filmie Marczewskiego, samotnie patrzeć przez okno na ulicę.

Przytoczone tytuły warte były przypomnienia, gdyż noszą w sobie pamięć (a niekiedy także zapowiedź) przemian dokonujących się w historii myśli filmowej $\mathrm{w}$ odniesieniu do specyficznej sytuacji odbiorczej widza w kinie. Ucieczka z kina Wolność wpisuje się avant la lettre w uprawianą dość szeroko w ostatnich latach sensualną teorię kina. W równej mierze można by jednak podać w wątpliwość fakt, że było to rzeczywiście avant la lettre i uznać film Wojciecha Marczewskiego 
za efekt „pracy teorii” wcześniejszego okresu. Artysta bowiem - właściwymi sobie środkami, w języku swojej sztuki - mówi często to samo, co w innym, dyskursywnym języku wcześniej albo później wypowiadaja uczeni ${ }^{15}$.

Teoretycy czasem niewiele się różnią od fachowców wykonujących domowe naprawy, jakkolwiek obrazoburczo by to zabrzmiało; jedni i drudzy prawie zawsze uważają że ich poprzednicy zrobili wszystko nie tak, jak należy. JeanLouis Baudry, który twierdził, że cała wcześniejsza teoria wrażenia realności była błędna, bo opierała się na zasadzie podobieństwa filmu do rzeczywistości, czy Edgar Morin, który bez zbędnej skromności sam oznajmił, że dokonał „przełomu kopernikańskiego", to kilka z wielu przykładów. Dokonujący się współcześnie zwrot sensualny w badaniach nad kinem także może nasuwać takie skojarzenia. „Przepisanie na nowo" historii myśli filmowej przez Thomasa Elsaessera i Malte Hagenera jest tego wyrazistym dowodem. Jednocześnie, czytając konstatacje teoretyczne z tego kręgu, trudno nie odnieść wrażenia, że były one obecne w refleksji nad filmem dużo wcześniej i że obecny zwrot ku cielesności jest jedynie logiczną konsekwencją wcześniejszych teorii, ewolucją myśli, a nie rewolucją. Podkreślają to zresztą sami autorzy książki Teoria filmu: wprowadzenie przez zmysty, którzy, choć deklaruja że wchodza w szranki z istniejacymi propozycjami teoretycznymi ${ }^{16}$, przypominają też, że pytania, jakie stawiają, zostały już wcześniej wydobyte na światto dzienne, ale pozostały bez satysfakcjonujących odpowiedzi ${ }^{17}$. Marta Stańczyk wśród prekursorów myśli Vivian Sobchack wymienia między innymi Rudolfa Arnheima, Hugona Münsterberga, Jeana Epsteina, Jurija Timoszenkę i Siergieja Eisensteina ${ }^{18}$. Studiując historię myśli filmowej, łatwo jednak zauważyć, że było ich więcej. Warto podkreślić zasługi na tym polu przede wszystkim filmologów francuskich, o których autorzy współcześni bardzo łatwo zapominaja, a którzy zapoczątkowali większość wątków późniejszej teorii filmu - to oni wszak badali u widzów reakcje fizjologiczne na oglądany film, napięcie mięśniowe, zmiany rytmu oddechu... Trudno o bardziej wyrazisty dowód zainteresowania cielesnością i zmysłami odbiorcy. Powyższych uwag nie należy jednak traktować jako krytyki sensuous theory, wszak sami jej przedstawiciele wskazują na swoich teoretycznych antenatów, a Marta Stańczyk w zakończeniu cytowanego artykułu określa ją mianem odważnej $w$ swej zachowawczości, awangardowej w archaizmie ${ }^{19}$. Jej powiązanie z przeszłością mogłoby raczej świadczyć o tym, że zmysłowe, cielesne aspekty statusu widza w naturalny sposób są integralną częścią sytuacji odbiorczej. Można się dzisiaj spotkać z poglądem, że rozwój myśli filmowej od zawsze zmierzał w tym kierunku, a dominację paradygmatu semiopsychoanalitycznego od początku lat 60 . XX w. należy potraktować jako przejściowe zakłócenie tego naturalnego biegu rzeczy. W zwięzły sposób podsumowuje to Emad Moaddab: Teoretycy filmu we wczesnym okresie swojej działalności podkreślali cielesne cechy medium oraz związek między kinem a zmysłami widzów. Jednakże, w przeciwieństwie do wczesnej koncentracji kina na cielesnej identyfikacji publiczności z filmem, ewolucja języka kinematograficznego, a następnie dominujacego systemu narracji uformowała się w kierunku identyfikacji z narracja, a to, co byto zwiazane ze sfera cielesna, zostało przeniesione do sfery umystu. Przejście to doprowadziło do długiej supremacji teorii filmu, opierajacych sie na lingwistyce i psychologii filmu ${ }^{20}$.

Traktowanie dominującej w latach 70. i 80. XX w. psychoanalitycznej teorii kina wyłącznie w kategoriach zakłócenia „właściwego” biegu historii myśli filmo- 
wej byłoby jednak ewidentnym uproszczeniem. Dużo bardziej adekwatne wydaje się tu podejście dialektyczne. Zarówno bowiem teoria psychoanalityczna, jak i sensuous theory przedmiotem swej refleksji czynią ten sam fenomen: jedyne w swej istocie i nieporównywalne z niczym innym doświadczenie kina. Choć $\mathrm{w}$ warstwie polemicznej zmysłowa teoria filmu kwestionuje ugruntowaną przez wcześniejszą koncepcję dominację wzroku w kinie, trudno nie odnieść wrażenia, że tak rozważania psychoanalityczne, jak i refleksje poszczególnych autorów, którzy bądź to związali się przejściowo z psychoanalizą jak Roland Barthes, bądź się wobec niej dystansowali, jak Jean-Louis Schefer, krążyły w gruncie rzeczy wokół tych samych problemów, jakie zaprzątają teoretyków filmu w ostatnich kilkunastu latach - doświadczania przez widza sytuacji kinowej. Zaś różnice pomiędzy poszczególnymi koncepcjami sprowadzają się głównie do tego, na jaki aspekt tego doświadczenia zostaje położony nacisk. Podsumowuje to niezwykle trafnie Justyna Budzik, posługując się przy tym terminem wywodzącym się między innymi z tradycji psychoanalizy kina: Dyspozytyw kina jest czasoprzestrzenia multisensoryczna, a szczególna rolę odgrywa w niej wspótistnienie wzroku i dotyku²1.

Dominująca współcześnie sensuous theory często, zdaje się, zapomina o jednym istotnym aspekcie recepcji filmu. Pisząc o cielesności kina w koncepcjach takich autorów, jak Tom Gunning, Vivian Sobchack, Miriam Hansen czy Steven Shaviro, Marta Stańczyk precyzuje, że zagadnienie to może być rozpatrywane w odniesieniu do filmowych reprezentacji cielesności, do materialności samego medium, do ciała aktora i wreszcie, co najbardziej istotne, do ciała konkretnego widza. Spotyka się także - w końcu - z otoczeniem: ciałami innych widzów, ale też kinem w jego materialności ${ }^{22}$. Obecność innych zostaje tu wprawdzie wymieniona, lecz dopiero „w końcu”, na ostatnim miejscu. Użyte wcześniej słowo „zapominać” nie jest tu jednak do końca właściwe, gdyż przyjęty w naszej kulturze sposób funkcjonowania kina w dużej mierze nie pozwala temu aspektowi zaistnieć. Psychoanalityczna teoria kina koncentrowała się przede wszystkim na zmyśle wzroku, kognitywizm na procesach poznawczych i myślowych, sensuous theory dołącza do tego także inne zmysły, z dotykiem na czele. Wszystkie te koncepcje przedmiotem swego zainteresowania czynią jednak z reguły pojedynczego widza, wid za samotne go. Wyjątku nie stanowi nawet Roland Barthes, dla którego obecność innych widzów w mroku sali jest jedynie „elementem tła”, czynnikiem kreującym atmosferę podniecenia erotycznego. Może wyróżnia się w tym gronie Jean-Louis Schefer, dla którego ważne jest, w jakim stopniu jego własne odczucia jako widza są wspólne całemu gatunkowi, innym ludziom, jednak w konkretnej sytuacji recepcji filmu „zwyczajny człowiek w kinie” także jest sam na sam ze swoim strachem i niepokojem. Model kina, który ukonstytuował się w naszej kulturze, opiera się na izolacji ludzi; nie potrzeba do tego pandemii.

Bez względu na to, z iloma osobami oglądamy film, zawsze jesteśmy sami w kinie - mówił Christian Metz ${ }^{23}$. Wspólnotowe formy recepcji filmu, choć w dzisiejszych czasach ponownie znajdują amatorów ${ }^{24}$, są kojarzone przede wszystkim z minionymi etapami społecznego funkcjonowania kina (doświadczenia Flaherty'ego, Kino Paradiso). Fakt, że teorie filmu często „zapominają” o obecności innych osób, z którymi widz ogląda film ${ }^{25}$, zostaje tu więc przywołany nie po to, by czynić im z tego zarzut. Jest to bowiem „biała plama”, podobna do tych, o których wspominała Alicja Helman: jeśli dany temat nie został w dostatecznym stopniu omó- 
wiony przez teoretyków, to, być może, należy uznać ten fakt za znaczący? ${ }^{26}$ Teoria filmu nie zapomina o innych widzach, po prostu nie są oni dla niej tematem pierwszej wagi.

Niektóre słowa umarty, mimo że ich jeszcze używamy - mówił Jerzy Grotowski. - Sa takie, które umarty, nie dlatego, że należałoby je zastapić innymi, ale dlatego, że umiera to, co oznaczaja. Tak jest przynajmniej dla wielu z nas. Do takich słów należy: spektakl, przedstawienie, teatr, widz itd. A co jest potrzebne? Co żyje? (...) Co jest możliwe wspólnie? Święto ${ }^{27}$.

Grotowski wygłosił powyższe słowa w 1970 r. w auli New York University, wieszcząc upadek tradycyjnego spektaklu. Wypowiadając je, miał na myśli konieczność wprowadzenia zmian w łonie współczesnego teatru, w zadziwiający sposób jednak współbrzmi z nimi późniejsza o zaledwie parę lat konstatacja Christiana Zimmera, odnosząca się do kina: Spektakl (reprezentacja) wznióst swoje imperium na ruinach święta ${ }^{28}$.

Wypowiedź Zimmera odnosi się przede wszystkim do spektaklu filmowego, a przynajmniej odnosi ją do niego autor znakomitego, niedostatecznie, jak sądzę, docenionego w piśmiennictwie filmowym artykułu Spektakl filmowy: fenomen w stadium rozpoznania, Wojciecha Chyły ${ }^{29}$. Analizowana w tym tekście książka Zimmera jest oczywiście ufundowana na dominujących w drugiej połowie lat 70 . ideach psychoanalitycznych i neomarksistowskich, traktujących spektakl kinematograficzny w kategoriach produkcji i konsumpcji oraz zastępczego spełniania pragnień, czyli, inaczej mówiąc - utowarowienia uczuć. Prognoz Zimmera i Chyły nie należy jednak lekceważyć jako przestarzałych, zwłaszcza że określenie to w ogóle nijak się ma do rozwoju myśli ludzkiej - nowsze teorie nie zawsze są trafniejsze od dawnych, mają jedynie większą w danym momencie historycznym siłę przebicia $^{30}$. W rozważaniach nad spektaklem filmowym najbardziej płodne intelektualnie do dziś wydają się uwagi dotyczące jego uwarunkowań antropologicznych. W rozdziale poświęconym temu zagadnieniu Chyła pyta, jak doszło do tego, że wyrzekliśmy się święta - tej unikalnej szansy reprezentowania się nas samych przeciw ustalonemu porzadkowi rzeczy, a zadowoliliśmy się ogladaniem danej nam do patrzenia reprezentacji tego porzadk $u^{31}$, jak iluzja spektaklu zastapita zachwyt i oczarowanie świętem (...) jak obowiazująca samotność filmowego widza zastapita nieodzownie kolektywny charakter święta ${ }^{32}$ i znajduje odpowiedź w charakterystycznej dla naszej cywilizacji spektaklu hipertrofii wzroku, która każe zapomnieć o naszej cielesności. Krytyka dominacji zmysłu wzroku jest więc obecna w refleksji nad filmem od dawna, nawet wówczas, gdy dominującym modelem jej uprawiania jest krytykowana przez sensuous theory psychoanaliza. Warto przy tym podkreślić, że krytyka ta ma charakter głęboki, nie ogranicza się jedynie do stwierdzenia tego faktu i uznania go za błąd. Krytyka hipertrofii wzroku jest w książce Zimmera równoznaczna z krytyką cywilizacji, która opiera się na niezwykle dynamicznym rozwoju technik reprezentacji. Stanowi zatem jednocześnie wytłumaczenie, jakie jest źródło dominacji zmysłu wzroku między innymi w kinie, oraz konstatację, że jest ona nieuchronna. Choć przedstawiciele sensuous theory starają się ją kwestionować, pozostaje faktem, że w ich rozważaniach odczucia widza związane z uaktywnieniem w trakcie seansu innych zmysłów niż wzrok są często uwarunkowane pewnym szczególnym typem filmów - to przede wszystkim one budzą zmysły, a nie sytuacja oglądania filmu en général. Uprzywilejowane miejsce w tych rozważaniach 
zajmują zwłaszcza filmy francuskiego ekstremizmu, niektóre gatunki filmowe (np. horror) oraz filmy epatujące erotyzmem - wyrazistym przykładem tych ostatnich może być Apollonide (2011) Bertranda Bonello, z upodobaniem analizowana przez autorów francuskich ${ }^{33}$.

Jest słowo na takich jak wy: publiczność - pisze Florian Malzacher, modyfikując nieco monolog Richarda Lowdona skierowany do widzów teatru Forced Entertainment ${ }^{34}$. Słowa takie można wypowiedzieć w teatrze, nie są one już jednak tak oczywiste w kinie. Tu pojawia się przede wszystkim wi d z, zaangażowany uczuciowo i intelektualnie, odczuwający reakcje swego ciała, ale wciąż nieodwołalnie samotny. (...) bez watpienia, dyspozytyw sali kinowej zakłada taki model zgromadzenia widzów, który jest zbudowany na ich konstytutywnej samotności, w przeciwieństwie do publiczności teatralnej, która tworzy całość cechująca się w większym stopniu przynależnościa do pewnej zbiorowości, a nie jedynie sumę osobnych jednostek - zauważa Nicolas Poirier $^{35}$.

Czy istnieje zatem zdalne kino? Powiedzmy sobie szczerze: deklaracja krakowskiego kina była po prostu chwytem marketingowym. Ale odpowiedź na powyższe pytanie jest w sposób oczywisty twierdząca: tak, istnieje wyłącznie zdalne kino! Widz filmowy jest zawsze $\mathrm{z}$ d a la od świata przedstawionego i w równym stopniu, choć czasami blisko fizycznie, z dala od innych ludzi. Gest Cenzora dotykającego dłonią ekranu jest w tym kontekście symbolem odwiecznego, nie tylko w kinie, ludzkiego marzenia, aby dotknąć tego, co niedotykalne i przełamać własną samotność: Zawsze chciałem tu wejść...

Nie wiem, czy spotkanie widzów "Nowojorskiego kina” jest tylko przelotne, ufundowane na intymności kinowej. Może więź, która wytworzyła się między nimi na linii kompozycji w mroku, nie zerwie sie po zakończeniu projekcji, a sensualne podniecenie rozbłyśnie w pełnym świetle sali ${ }^{36}$ - wyraża nadzieję Justyna Budzik, analizując sytuację kinową przedstawioną na obrazie Edwarda Hoppera. Jakkolwiek pięknie by to brzmiało, szanse na zaistnienie tej wspólnoty kinowej są w dzisiejszych czasach raczej niewielkie. Nawet wykreowana w świecie fikcji wspólnota widzów kina Paradiso nie była w stanie oprzeć się próbie czasu. Tornatore stworzył wprawdzie jeden z najpiękniejszych portretów zbiorowości, w ramach której każdy z osobna, lecz w poczuciu wspólnoty uczuć (chacun son cinéma), przeżywa oglądany film, lecz na koniec, w scenach bardziej współczesnych, pozostawia nas z obrazem samotnego Salvatore w pustej sali kinowej. Także pod tym względem Ucieczka z kina Wolność dostarcza ciekawego materiału do refleksji: aby zapobiec zamieszkom, Cenzor każe wykupić wszystkie bilety i wyświetlać film przy pustej sali; jednak tworzy w ten sposób nie kino bez widzów, ale kino dla jednego widza. Jest nim on sam, samotny w pustej sali.

„Pandemiczna” próba przekonania nas do idei zdalnego kina, jakkolwiek miała przyczyny natury ekonomicznej (wsparcie instytucji kultury), to kolejny krok w kierunku, który wieszczył już Christian Zimmer. Dla niego samo siedzenie w kinie przed ekranem było symptomem alienacji współczesnego człowieka, bytowaniem „na ruinach święta”; dzisiaj wyobrażamy sobie, że jesteśmy w kinie. Zabrano nam zatem nawet ten rodzaj iluzorycznej wspólnoty, którą definiuje w swych pracach, pod nazwą „efektu widza" ${ }^{37}$, Julian Hanich (jeśli siedzimy obok siebie i skupiamy się na tym samym, to jest to już doświadczenie kolektywne, w pewien sposób oddziałujemy na siebie samą obecnością). 
Brak pogłębionej refleksji nad współobecnością innych widzów, widoczny w myśli filmowej przez długie lata jej historii, ma z pewnością charakter znaczący. Jednocześnie podskórnie jest ona stale obecna w rozważaniach nad recepcją filmu, wypływając już jawnie w ujęciu wspomnianego tu Juliana Hanicha. Ta ambiwalencja nie jest niczym zaskakującym w teorii filmu, a zwłaszcza w teorii widza filmowego; dwuznaczny status ontologiczny filmu stanowi wręcz o jego specyfice. Film zarazem jest i nie jest podobny do rzeczywistości, a widz ogląda go w stanie jednoczesnej wiary i niewiary: dobrze wiem, a jednak... ${ }^{38}$ Sformułowania te były charakterystyczne dla Christiana Metza, ale pozostają aktualne do dziś, także w ramach „,awangardowych archaicznych teorii”, nie pozwalając zapomnieć o „podejrzanym”, płynnym charakterze filmu i jego odbiorcy. Bowiem czy tego chcemy, czy nie, dawna teoria jest wciąż obecna w teoriach nowych, stanowiąc niekwestionowane dziedzictwo kulturowe myśli ludzkiej. Pojawiające się w niniejszym tekście parokrotnie nazwisko Metza jest tego widomym wyrazem. Choć jest to temat na osobny artykuł, warto zauważyć, że tak jak kiedyś jego rola w historii myśli filmowej była, być może, nawet przeceniana, tak obecnie jest niedoceniana, a jego teoria utożsamiana jedynie $\mathrm{z}$ powierzchownie pojmowaną psychoanalizą. Z całą pewnością autor Le signifiant imaginaire w kontrowersyjny sposób aplikował teorię Lacana, ale jednocześnie w jego książce można odnaleźć wiele aktualnych i nadal inspirujących spostrzeżeń na temat doświadczenia kina. W pewnym stopniu dotyczą one nawet zmysłowej recepcji filmu. (...) wiem, że moja percepcja jest realna, że moje zmysty sa fizycznie zaangażowane ${ }^{39}$ - pisze Metz o sobie jako widzu.

W kinie towarzyszy nam obecność innych ludzi; wielu widzom może jej brakować w sytuacji odbioru zdalnego, czy jednak rzeczywiście można tu mówić o wspólnocie w pełnym tego słowa znaczeniu? Jeśli tak, to jest to wspólnota „,wielkomiejska”, jak mógłby powiedzieć Barthes ${ }^{40}$, charakterystyczna dla naszych czasów w tym ich aspekcie, który zgodnie piętnowali Grotowski i Zimmer. Mimo upływu około pięćdziesięciu lat ich diagnozy nie straciły na aktualności, poszliśmy nawet w naszkicowanym przez nich kierunku o parę kroków dalej. Ta „wspólnota" polega na tym, że jesteśmy wśród ludzi, którzy czują podobnie jak my, ale są od nas oddzieleni swego rodzaju niewidzialną bariera, niepozwalającą na prawdziwy kontakt, może trochę jak tłum obcych osób w galerii handlowej? One także przecież mają wspólny cel, choć najczęściej nie jest nim przeżycie estetyczne. Zatem mamy tu do czynienia z obecnością wokół nas innych ciał, o której informują nas zmysły, ale jednak bardziej „ilościową”, nieukierunkowaną na jakość kontaktu.

Kino jest, być może, najbardziej trafnym symbolem kondycji współczesnego człowieka - nieprzypadkowo zaistniało ono w epoce nowoczesnej, a potem ponowoczesnej, w ścisłym związku z kulturą miejską. Z cała pewnością kinoman to miejski człowiek, a kino wpisane jest w przestrzeń miejską. To tu możemy w samotności rozkoszować się wrażeniem, którego przed chwila doznaliśmy, skrywając się w masie nieznajomych $l u d z i^{41}$. Francuski filozof Dominique Chateau, wychodząc między innymi od definicji nowoczesności Charlesa Baudelaire'a, poświęcił całą książkę temu aspektowi kina ${ }^{42}$. Daje nam ono poczucie obecności - świata na ekranie, ludzi wokół nas, naszych własnych zmysłów i uczuć - ale czyni to kosztem realnego, bliskiego kontaktu z innym, wprowadza, jak w czasach epidemii, dystans społeczny. 
Antoine de Saint Exupéry mówił, że kochać to nie znaczy patrzeć na siebie nawzajem, ale patrzeć razem w tym samym kierunku ${ }^{43}$. W tym sensie można by paradoksalnie stwierdzić, że grupa widzów patrzących na ekran i przeżywających podobne uczucia jest rzeczywiście wspólnotą połączoną miłością; w tym wypadku jednak nie miłością do innych, lecz do kina.

Obecność na sali, wśród innych ludzi, z całą pewnością ma dla widza kinowego znaczenie (przynajmniej dla istotnej części ogółu odbiorców, gdyż refleksje dotyczące recepcji filmu zawsze muszą uwzględniać psychologię różnic indywidualnych), ale wspólnota, która w wyniku tej zmysłowej współobecności powstaje, ma charakter w gruncie rzeczy iluzoryczny. Często mówi się o tym, że kino zapewnia nam możliwość bezpiecznego przeżywania emocji, które w życiu musiałyby się wiązać z realnym zagrożeniem, na przykład strachu generowanego przez horrory. Bezpieczeństwo w kinie dotyczy jednak także specyfiki relacji, w jakiej widz znajduje się z innymi uczestnikami seansu: nie jest sam, ale nie chce, aby inni nawiązali z nim bezpośredni kontakt. Wyjątkiem są projekcje „prywatne”, które nie zawsze muszą być tak nudne, jak sugerował Barthes ${ }^{44}, \mathrm{w}$ tym jednak wypadku realny kontakt między ludźmi istnieje już przed seansem, a ten ostatni jest tylko dopełnieniem relacji między nimi.

Ostatecznie film $i$ widz sa jak para pasożyt $i \dot{z} y w i c i e l$, wymieniajacy się rolami aż do chwili, kiedy istnieje już tylko jedna rzeczywistość - piszą autorzy Teorii filmu: wprowadzenia przez zmysty ${ }^{45}$. Inni widzowie na tej - tak pięknie opisanej przez Wong Kar Waia - ciemnej, skapanej w uczuciu oczekiwania sali są nam potrzebni głównie po to, byśmy mieli poczucie, że jesteśmy w prawdziwym, a nie zdalnym, kinie.

${ }^{1}$ Cyt. za [B. a.], Kinematografia. Emocjonalnie o filmach czy filmowo o emocjach?, https://kinemotografia.wordpress.com/ (dostęp: 30.05.2020)

${ }^{2}$ https://www.e-kinopodbaranami.pl/. W podobnym duchu zapraszało na powstałą nieco później platformę MOJEeKINO.PL Stowarzyszenie Kin Studyjnych.

${ }^{3}$ Nie dyskredytuję tu $\mathrm{w}$ żadnej mierze tych, które mówią o powstawaniu filmu - jak Osiem i pót (8 1⁄2, reż. Federico Fellini, 1963), Noc amerykańska (La nuit américaine, reż. François Truffaut, 1973) czy Niewolnica miłości (Raba ljubwi, reż. Nikita Michałkow, 1976), często jednak, nierzadko w sposób humorystyczny czy wręcz groteskowy, opowiadają one raczej o męce tworzenia niż o radości obcowania z X Muzą.

${ }^{4} \mathrm{~J}$. Budzik, Dotyk światła. O zmysłowym doznawaniu kina, FA-art, Katowice 2012, s. 58.

${ }^{5}$ A. Gwóźdź, Wprowadzenie, w: Pamięć kina, red. A. Gwóźdź, Wydawnictwo Naukowe „Śląsk”, Katowice 2013, s. 7.

${ }^{6}$ Zob. J.-L. Schefer, L'homme ordinaire du cinéma, Cahiers du Cinéma-Gallimard, Paris 1980.
${ }^{7}$ Określenie filmu autorstwa Ricciotta Canudo.

${ }^{8}$ Zob. R. Barthes, Wychodzac z kina, tłum. Ł. Demby, w: Interpretacja dzieła filmowego. Antologia przekładów, red. W. Godzic, Wydawnictwo Uniwersytetu Jagiellońskiego, Kraków 1993.

${ }^{9}$ J. Hanich, Watching a Film With Others: Towards a Theory of Collective Spectatorship, „Screen" 2014, t. 55, nr 3, s. 338.

${ }^{10}$ Warto zaznaczyć, że w piśmiennictwie francuskim, na określenie sztuki filmowej w dużo większym stopniu niż w polskim, używane jest słowo „kino” (zamiast „film”).

${ }^{11}$ Zob. J.-L. Comolli, Cinéma, numérique, survie. L'art du Temps, ENS Éditions, Lyon 2019, s. 173 i nast.

12 Zob. J. Pallasmaa, Oczy skóry. Architektura i zmysty, tłum. M. Choptiany, Fundacja Instytut Architektury, Kraków 2012.

${ }^{13}$ Zob. J. Rek, Między filmowym analfabetyzmem a kompetencja. Przyczynek do antropologii filmu, w: Film: tekst $i$ kontekst, red. A. Helman, W. Godzic, Uniwersytet Śląski, Katowice 1982, s. 41. 
${ }^{14}$ Zob. Ch. Metz, Le signifiant imaginaire. Psychanalyse et cinéma, Union Générale d'Editions, Paris 1977, s. 123.

${ }^{15} \mathrm{~T}$. Lubelski, Interpretacja Jungiem podszyta (na przykładzie "Osiem i pót" i innych filmów o samourzeczywistnieniu), w: Interpretacja dzieła, red. M. Czerwiński, Zakład Narodowy im. Ossolińskich, Wrocław 1987, s. 183.

${ }^{16}$ T. Elsaesser, M. Hagener, Teoria filmu: wprowadzenie przez zmysty, tłum. K. Wojnowski, Universitas, Kraków 2015, s. 13.

17 Tamże, s. 16.

18 Zob. M. Stańczyk, Zmysłowa teoria kina, „Ekrany” 2015, nr 3-4, s. 70.

19 Tamże, s. 75.

${ }^{20}$ E. Moaddab, Audience Embodiment in Haptic Space of Film, "European Online Journal of Natural and Social Sciences" 2014, t. 3, nr 4 (Special Issue on Architecture, Urbanism, and Civil Engineering), s. 59. Artykuł dostępny online: https://pdfs.semanticscholar.org/f371/6846ea4568e74b4c5baeb07459499df39f2.pdf (dostęp: 30.05.2020)

${ }^{21}$ J. Budzik, dz. cyt., s. 14.

${ }^{22}$ M. Stańczyk, Ucieleśnione doświadczenie kinowe. "Sensuous theory" i jej krytyczny potencjat. Niepublikowana praca doktorska, Uniwersytet Jagielloński, Instytut Sztuk Audiowizualnych, Kraków 2020, s. 96.

${ }^{23}$ Por. Ch. Metz, dz. cyt., s. 135.

${ }^{24}$ Bardzo ciekawe opracowanie tego zjawiska można odnaleźć w: A. Koźmińska, Spotkania z filmem w przestrzeni miejskiej na przykładzie nieformalnych publicznych projekcji w Krakowie. Niepublikowana praca magisterska, Uniwersytet Jagielloński, Instytut Sztuk Audiowizualnych, Kraków 2014.

25 Pisze o tym między innymi Julian Hanich, uzasadniając w ten sposób sens i konieczność prowadzonych przez siebie badań.

${ }^{26}$ Por. A. Helman, Sposoby uprawiania teorii filmu, w: Prędkość i przyjemność, red. A. Gwóźdź, Wydawnictwo Szumacher, Kielce 1994, s. 15.

${ }^{27}$ J. Grotowski, Święto, „Odra” 1972, nr 6, s. 47.

${ }^{28} \mathrm{Ch}$. Zimmer, Procès du spectacle. Essai sur le cinéma et les autres formes de spectacle, Ed. PUF, Paris 1977, s. 101.

${ }^{29}$ W. Chyła, Spektakl filmowy: fenomen w stadium rozpoznania, w: Estetyka i struktura dzieła filmowego, red. J. Trzynadlowski, Wydawnictwo Uniwersytetu Wrocławskiego, Wrocław 1987.
${ }^{30}$ Pisał o tym przed laty, w odniesieniu do teorii logocentrycznych, takich jak semiologia i psychoanaliza, Ernest Wilde, ale jego refleksje pozostają w dużej mierze aktualne także w odniesieniu do późniejszych teorii. Por. E. Wilde, O języku i stylu wspótczesnej teorii filmu, w: Autor - film - odbiorca, red. A. Helman, Wiedza o kulturze, Wrocław 1991.

${ }^{31}$ W. Chyła, dz. cyt., s. 25.

32 Tamże.

${ }^{33}$ Zob. m.in. R. Chareyron, Comprendre par les sens: Pour une rapproche tactile de "L'Apollonide”, „Entrelacs. Cinéma et audiovisuel” 2013, nr 10.

${ }^{34} \mathrm{~F}$. Malzacher, Jest stowo na takich jak wy: publiczność. Widz jako zły świadek $i$ zły voyeur, w: Tak jakby nic się nie wydarzyło. Teatr Forced Entertainment, red. K. Tórz, Fundacja Malta\&Ha!art, Poznań-Kraków 2015, s. 127.

${ }^{35}$ N. Poirier, Le spectateur de cinéma, http://www.debordements.fr/Le-spectateur-de-cinema (dostęp: 28.05.2020).

${ }^{36}$ J. Budzik, dz. cyt., s. 53.

37 Zob. J. Hanich, The Audience Effect. On the Collective Cinema Experience, Edinburgh University Press, Edinburgh 2018. Termin efekt widza (znany także pod innymi nazwami rozproszenie odpowiedzialności, dyfuzja odpowiedzialności, efekt obojętnego przechodnia) autor zapożyczył z psychologii społecznej (m.in. z badań Johna Darleya i Bibba Latanégo), w której jednak ma on inne, mniej dosłowne znaczenie i dotyczy zjawiska określanego potocznie jako „znieczulica społeczna", a więc nieudzielania pomocy w sytuacji, gdy ktoś inny może to zrobić.

${ }^{38}$ Zob. Ch. Metz, dz. cyt., s. 98-100.

${ }^{39}$ Ch. Metz, dz. cyt., s. 69.

${ }^{40}$ Por. R. Barthes, dz. cyt.

${ }^{41}$ J. Kowalkowska, Kinoman - miejski człowiek, „Kultura Miasta” 2008, nr 2-3, s. 35.

${ }^{42}$ Zob. D. Chateau, Philosophie d'un art moderne: le cinéma, Éditions L'Harmattan, Paris 2009.

${ }^{43}$ A. de Saint-Exupéry, Ziemia, planeta ludzi, tłum. W. i Z. Bieńkowscy, Arcanum, Bydgoszcz 1991, s. 119.

44 (...) o, nudo i frustracjo projekcji zwanych prywatnymi! (R. Barthes, Wychodzac z kina, dz. cyt., s. 158).

${ }^{45}$ T. Elsaesser, M. Hagener, dz. cyt., s. 22. 


\section{Lucja Demby}

Dr hab., profesor w Instytucie Sztuk Audiowizualnych Uniwersytetu Jagiellońskiego w Krakowie. Interesuje się teorią i analizą filmu, prowadzi także badania interdyscyplinarne z pogranicza filmu, muzyki i teatru. Autorka książki Poza rzeczywistościa. Spór o wrażenie realności w historii francuskiej myśli filmowej (2002). Jej książka Harmonia śziata. Twórczość filmowa Nikity Michatkowa (2009) jest pierwszą naukową monografią dorobku rosyjskiego reżysera. W ostatnich latach przedmiotem jej zainteresowania jest także polski serial telewizyjny.

\section{Bibliografia}

Barthes, R. (1993). Wychodząc z kina (thum. Ł. Demby). W: W. Godzic (red.), Interpretacja dzieła filmowego. Antologia przekładów. Kraków: Wydawnictwo Uniwersytetu Jagiellońskiego.

Budzik, J. (2012). Dotyk światła. O zmysłowym doznawaniu kina. Katowice: Wydawnictwo FA-art.

Chareyron, R. (2013). Comprendre par les sens: Pour une rapproche tactile de „L'Apollonide". Entrelacs. Cinéma et audiovisuel, 10, ss. 1-10. https://doi.org/10.400o/entrelacs. 528

Chateau, D. (2009). Philosophie d'un art moderne: le cinéma. Paris: Éditions L'Harmattan. Chyla, W. (1987). Spektakl filmowy: fenomen w stadium rozpoznania. W: J. Trzynadlowski (red.), Estetyka i struktura dzieła filmowego. Wrocław: Wydawnictwo Uniwersytetu Wrocławskiego.

Elsaesser T., Hagener M. (2015). Teoria filmu: woprowadzenie przez zmysty (thum. K. Wojnowski). Kraków: Universitas.

Grotowski, J. (1972). Święto. Odra, 6, ss. 47-51.

Gwóźdź, A. (red.) (2013). Pamięć kina. Katowice: Wydawnictwo Naukowe „Śląsk”.

Hanich, J. (2014). Watching a Film With Others: Towards a Theory of Collective Spectatorship. Screen, 55 (3), ss. 338-359. https://doi.org/10.1093/screen/hjuo26

Hanich, J. (2018). The Audience Effect: On the Collective Cinema Experience. Edinburgh: Edinburgh University Press.

Helman, A. (1994). Sposoby uprawiania teorii filmu. W: A. Gwóźdź (red.), Prędkość i przyjemność. Kielce: Wydawnictwo Szumacher.

Kowalkowska, J. (2008). Kinoman - miejski człowiek. Kultura Miasta, 2-3, ss. 35-37.

Koźmińska, A. (2014). Spotkania z filmem w przestrzeni miejskiej na przykładzie nieformalnych publicznych projekcji w Krakowie. Niepublikowana praca magisterska. Kraków: Uniwersytet Jagielloński, Instytut Sztuk Audiowizualnych.

Lubelski, T. (1987). Interpretacja fungiem podszyta (na przykładzie „Osiem i pót” $i$ innych filmów o samourzeczyzistnieniu). W: M. Czerwiński (red.), Interpretacja dzieła. Wrocław: Zakład Narodowy im. Ossolińskich.

Malzacher, F. (2015). Fest stowo na takich jak wy: publiczność. Widz jako zty śriadek $i$ zty voyeur. W: K. Tórz (red.), Tak jakby nic sie nie wydarzyto. Teatr Forced Enterainment. Poznań - Kraków: Fundacja Malta\&Ha!art. 
Metz, C. (1977). Le signifiant imaginaire. Psychanalyse et cinéma. Paris: Union Générale d'Editions.

Moaddab, E. (2014). Audience Embodiment in Haptic Space of Film. European Online Fournal of Natural and Social Sciences (Special Issue on Architecture, Urbanism, and Civil Engineering), 3 (4), ss. 55-65. https://pdfs.semanticscholar.org/f371/6846ea4568e74b4c5baeebo7459499df39f2.pdf

Pallasmaa, J. (2012). Oczy skóry. Architektura $i$ zmysty (tłum. M. Choptiany). Kraków: Fundacja Instytut Architektury.

Poirier, N. (2018, 31 stycznia). Le spectateur de cinéma. Débordements. http://www.debordements.fr/Le-spectateur-de-cinema

Rek, J. (1982). Między filmowym analfabetyzmem a kompetencją. Przyczynek do antropologii filmu. W: A. Helman, W. Godzic (red.), Film: tekst $i$ kontekst. Katowice: Wydawnictwo Uniwersytetu Śląskiego.

Schefer, J.-L. (1980). L'homme ordinaire du cinema. Paris: Cahiers du Cinéma - Gallimard.

Stańczyk, M. (2015). Zmysłowa teoria kina. Ekrany, 3-4, ss. 70-75.

Stańczyk, M. (2020). Ucieleśnione dośriadczenie kinowe. „Sensuous theory” i jej krytyczny potencjat. Niepublikowana praca doktorska. Kraków: Uniwersytet Jagielloński, Instytut Sztuk Audiowizualnych.

Wilde, E. (1991). O języku i stylu rospótczesnej teorii filmu. W: A. Helman (red.), Autor film - odbiorca. Wrocław: Wiedza o kulturze.

Zimmer, Ch. (1977). Procès du spectacle. Essai sur le cinéma et les autres formes de spectacle. Paris: Ed. PUF.

Keywords:

film theory;

film spectator

theory;

cinema experience;

remote cinema;

sensuous theory

\section{Abstract \\ Łucja Demby}

Remote Cinema. The Loneliness of the Spectator in Relation to the Sensuous Nature of Film Reception

The author draws the reader's attention to a new phenomenon that emerged during the coronavirus epidemic: "remote cinema". The author contemplates how this new situation differs from the ordinary experience of watching a film online. These deliberations are set in the context of selected aspects of film theory, regarding the spectator's distance towards the film and, above all, towards other spectators in the cinema. The author refers to sensuous theory, which has recently become dominant, but also to earlier theoretical concepts (such as psychoanalytic theory); she emphases the fact that present-day film reflection is largely rooted in them. As for the cinema experience, the focus is the paradoxical loneliness of the spectator. The author also refers to some film examples, in particular Escape from the 'Liberty' Cinema by Wojciech Marczewski. 